\title{
Anna Jędrzychowska
}

Wroclaw University of Economics and Business

e-mail: anna.jedrzychowska@ue.wroc.pl

ORCID: 0000-0002-3837-1734

\section{Ewa Poprawska}

Wroclaw University of Economics and Business

e-mail: ewa.poprawska@ue.wroc.pl

ORCID: 0000-0002-6024-6462

\section{COSTS INCURRED BY THE MOTHER AS A RESULT OF CHILDBIRTH AND UPBRINGING - CHANGES IN THE CAREER PATH}

\section{KOSZTY PONIESIONE PRZEZ MATKE W WYNIKU URODZENIA I WYCHOWANIA DZIECKA - ZMIANY W ŚCIEŻCE KARIERY ZAWODOWEJ}

DOI: $10.15611 /$ pn.2020.1.06

JEL Classification: G51, J13, J 32, H55, G22

Summary: The article is a part of research on the financial consequences of household members' loss of health and life, in this case - a child. The amount of this loss can be estimated using, among others, the cost approach, including expenses and lost benefits associated with raising a child. The article analyzes lost benefits - the financial consequences that the mother incurs mainly due to birth and childcare, and which are associated with changes in career development. Calculations are presented for selected scenarios for the career path and a model for assessing the income gap between women: mother and a childless one has been proposed. It should be remembered that the child appears most often at the beginning of the mother's professional career. This is the time of the fastest wage increase. Therefore, given the non-linear trend of wage increases with seniority (close to exponential), the 'severity' of the child's appearance in the initial period of work is significant.

Keywords: motherhood gap, personal injury, insurance.

Streszczenie: Artykuł jest kontynuacją badań dotyczących finansowych konsekwencji utraty zdrowia i życia przez członków gospodarstw domowych, w tym przypadku przez dziecko. Wysokość straty może być szacowana m.in. z użyciem podejścia kosztowego - rodzice ponoszą koszty (wydatki oraz utracone korzyści) związane z wychowaniem dziecka. W artykule analizowane są utracone korzyści, ponoszone przez matkę w związku z faktem urodzenia i opieki nad dzieckiem, które są związane ze zmianami w jej karierze zawodowej. Zaprezen- 


\begin{abstract}
towano kalkulacje dla wybranych scenariuszy rozwoju kariery zawodowej i zaproponowano model oceny luki dochodowej zdefiniowanej jako różnica między dochodami kobiety bezdzietnej i matki. Należy pamiętać, że dziecko pojawia się najczęściej na początku kariery zawodowej kobiety, gdy dynamika płac jest najwyższa (trend wzrostu płac wraz ze stażem pracy zbliżony do wykładniczego), w związku z czym konsekwencje wynikające z pojawienia się dziecka w początkowym okresie pracy zawodowej matki są znaczne.
\end{abstract}

Słowa kluczowe: luka dochodowa, szkody osobowe, ubezpieczenia.

\title{
1. Introduction
}

This paper is part of the broader research of the scientific team, concerning the financial consequences of loss of health and life for the households' members. Previously the authors analysed personal injury from the perspective of the changing claim culture and compensation trends on the market (Jędrzychowska and Kwiecień, 2016). The research concerned changes in household finances regarding several aspects. First of all, in terms of lost income (Jędrzychowska and Poprawska 2016), increased needs (Jędrzychowska, 2017), as well as from the side of the protection system resulting from compulsory third-party liability car insurance (Jędrzychowska and Poprawska, 2014; Ronka-Chmielowiec, Jędrzychowska, and Poprawska, 2015). Personal injury related to accidents at work was also analysed (Jędrzychowska and Kwiecień, 2015) as well as medical damage (Jędrzychowska, 2015). Currently, the authors are researching the damages for those indirectly affected (Jędrzychowska and Kwiecień, 2019).

Typical approaches that can be found in the literature for the analysis of the economic consequences of the loss of a household member include estimates based on the cost of production, the willingness to pay approach and the utility theory. The first of these approaches, cost of production, is based on the classical theory of economics (Murphy, 2006), which states that the value of a good is equal to the cost of its production. In this article, the authors analyse only a part of the loss - the costs of production. The research uses the theory about the valuation of goods, including the value of human life (in this case, the child's value), e.g. Hofflander (1966), Schultz (1961) and Becker (1975), Leimerg, Doyle, and Buck (1999), Letablier, Luci, Math, and Thévenon (2009) in addition to the sociological aspects, such as Zelizer (1994).

In this context, consideration is given to the problem related to the economic consequences of a child's death in a household. This problem is important in the context of the calculation the value of compensation for this loss (e.g. compensation from liability insurance). These consequences can be divided into:

A. Previously incurred costs:

A.1 previously incurred financial net expenses for a child including costs of pregnancy, the purchase of food, clothes, etc..

A.2 work previously done for the child (non-financial expenditure - "child service" e.g. taking a child to school, preparing meals, doing homework, cleaning). 
A.3 lost benefits (including the loss of spare time and changes in the career path).

B. Direct cost related to the child's death:

B.1 direct net expenses related to funeral,

B. 2 costs of treatment and psychological consultations related to trauma.

C. Expected future benefits from having had a child:

C.1 lost expected work performed by a child for a household (non-financial losses, especially crucial in agricultural families and large families, e.g. care for younger siblings, help with the house and agrarian work),

C.2 loss of expected old-age care (maintenance obligation of children to parents).

The article broadly analyses one of these aspects, i.e. lost profits (A.3), and focuses on one aspect of this problem: changes in the career development (especially in the case of the mother) related to having the break, and its slowdown as a result of the birth and subsequent care of the child. Selected scenarios of career path development are considered and an income gap assessment model is proposed. This gap arises as the difference between the expected career path of a childless person and a person with a child.

It should be emphasized that these considerations are a contribution to the discussion about compensation following the death of a child. Polish law (as well as in most EU countries) gives the members of the family of a deceased child a claim for compensation adequate to the extent of the damage suffered. This damage, according to regulations, includes: lost benefits, deterioration of life situation and pain and suffering (legal basis of par. 446 Civil Code).

This problem takes on a different scale depending on the economic situation of the country, social policy, social security in a given country, as well as cultural differences resulting from tradition, mentality and the dominant family model, etc. The problem is international and it is described as such. The created model of the valuation of the income gap is also universal, but the numerical illustration will be based on the Polish reality.

\section{Literature review}

In the literature on the subject one can find many justifications that motherhood penalty is significant to the gender wage gap. For example, studies by Glass (2004) found that the wage gap between women and men is bigger for the mother than for childless women. The research prepared by Staff and Jaylen (2012) shows that hourly wages of mothers are approximately $5 \%$ lower (per child) than the wages of nonmothers. The research by Sigle-Rushton and Waldfogel found that $81 \%$ of mothers with children under the age of 18 made less than $\$ 40,000$ per year compared to only $44 \%$ of fathers (Lips and Lawson 2009). The wage penalty incurred by women due to motherhood varies significantly across nations as do work-family policies. Therefore, it is unclear if variations in motherhood wage penalties are linked to specific work-family policies (Mielle, Misra, and Boeckmann, 2012). 
The article took into account the mother's situation, which is why there are more breaks in the career path, and that they are longer than for the father. The first reason for the change is related to the break in work associated with the period of pregnancy, which is sometimes related to recommendations for increased rest, some medical complications, and sometimes the necessity to break the work due to the professions with an increased risk such as hard physical work, work in medical jobs where there is contact with infectious diseases, etc. In Poland there is also the fact that the sickness benefit during pregnancy is equal to $100 \%$ of the salary. The second break in career is related to maternity leave and parental leave. In Poland, it is 20 weeks of fully-paid maternity leave, 32 weeks additional leave (the father can take this, but in practice almost exclusively the mother does), during which $60 \%$ of the salary is paid. The third reason for changes in career path, especially a slower wage growth, are frequent illnesses of children during the first few years of life. For this reason, especially mothers of young children are perceived by employers as worse than childless people and men (women mainly use medical allowances for childcare). These reasons cause interruptions in professional work and/or in the later period, a slower wage growth.

\section{Methodology of research}

The study was adopted as the basic (in terms of career development) option in which the woman has no child. Next, three variants were referred to, which indicate the different intensity of changes as a result of childbirth and the child's upbringing. Figure 1 shows the concept of the study and presents the differences in the analysed scenarios.

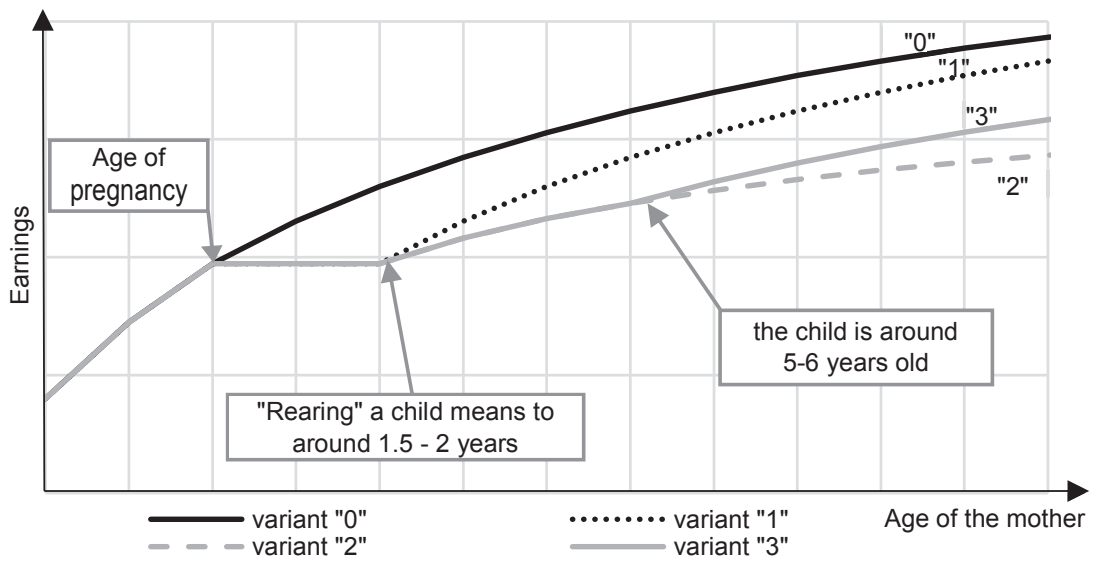

Fig. 1. Different scenarios of career development analysed in the study

Source: own work. 
Variant "0" - childless person (benchmark) - the wage growth rate throughout the entire period of work is equal to a statistical value according to the work experience.

Variant "1" - optimistic - break in work for two years (the salary level is constant in nominal value), then the wages are growing according to a statistical amount of the wage growth according to the work experience.

Variant "2" - pessimistic - break from work for two years (constant level of salary), then the salaries are growing according to the reduced wage growth rate because the mother 'missed' the moment of the best professional development.

Variant "3" - medium - break from work for two years (constant level of salary), for the next four years reduced wage growth rate (she still cannot get fully involved in the work, because of frequent medical assistance for the child), then a return to the statistical value of the wage growth based on the work experience.

In the analysis the wage growth rate is treated as a real growth rate, i.e. above inflation. Thus, the reported wages are also real values so that they can be compared with each other without additional calculations. In the analysis, the authors compare for all four options, the total amount of earnings earned over the entire career, that is, until retirement age.

\section{Numerical examples}

In the authors' opinion, four factors have a strong influence on the result (differences in the total amount of salary during the whole career). The first it the level of salary at the beginning of work. The next three factors concern the mother's age in such moments as starting work, getting pregnant, and retiring. In order to indicate the significance of these factors, assumptions for numerical examples were adopted:

- the level of salary at the beginning of work - it was assumed that the pay at the beginning of career path is equal to the average net salary in the economy,

- the age at the start of career - two cases are taken into consideration: a 20-year-old woman (without higher education), and a 25-year-old woman (a university graduate),

- the age of getting pregnant: after 1,5 and 10 years from the beginning of work,

- the age of retirement: assumed as 65 years.

The wage growth rate was calculated based on the Polish Central Statistical Office (GUS) published in "Structure of wages and salaries by occupations in October 2016". To simplify the calculations, it was assumed that the mother's age is counted at the beginning of the year, and the salary is paid at the end of the year (once a year in arrears). The data concerning the dependence between salary and length of work experience was used (Figure 2).

In addition the following economic assumptions were adopted in the calculations:

- inflation and the discount rate are equal to $2.5 \%$, and the value was taken following the inflation target set by the National Bank of Poland; 


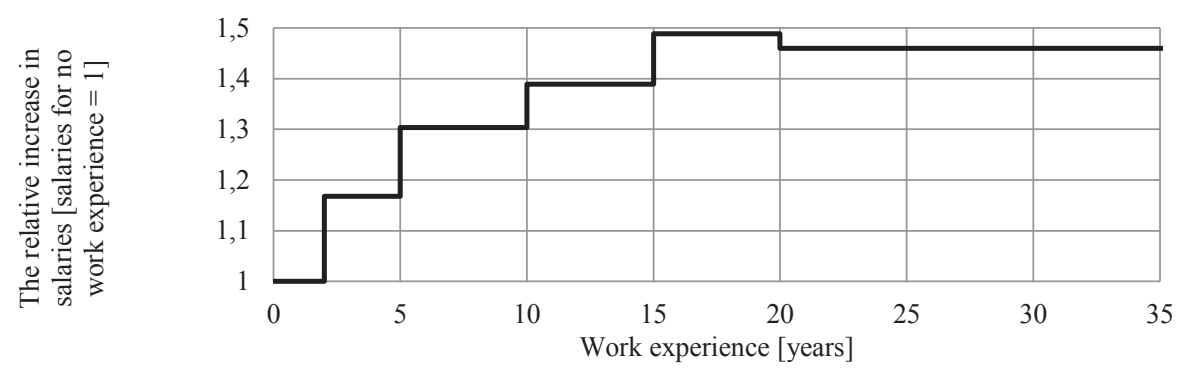

Fig. 2. The dependence of wages on the length of work experience - women 2016

Source: own work based on data published in (Central Statistical Office, 2016).

- $\quad$ PLN to EUR rate is $1 \mathrm{EUR}=4.30 \mathrm{PLN}$ (average exchange rate of the National Bank of Poland EUR to PLN from 30.07.2019: 1 EUR = 4.2906 PLN);

- monthly net earnings at the beginning of the career are equal to the average net salary in Poland (in the first quarter of 2019), that is 3,390 PLN, i.e. 788 EUR.

One more assumption was made regarding the reduced rate of pay growth in options 2 and 3, accepted by experts at the level of $10 \%$. The premise for the adoption of such a value was a position of reducing the employee's salary by $20 \%$ while being on sick leave. It was considered that the mother does not spend the whole year on sick leave and her salary and commitment to work (which gives, for example, wage bonuses) falls by $10 \%$ (half of the value from The Social Insurance Institution in Poland - ZUS).

The results of the calculations are given in Table 1.

The presented values show numerically the scale of the problem related to the break in work and childcare in the most straightforward scenarios -1 child at different moments in the mother's life. The most significant gap was obtained assuming scenario " 2 " in the situation of the earliest entering the labour market and the earliest child's birth (a 20-year-old woman starts work and a year later she gets pregnant). In this situation, the real value of the gap is $53,382 \mathrm{EUR}$, which is equivalent to approximately 68 monthly salaries. The lowest value was obtained in the case of the latest entry into the labour market and the latest pregnancy incidence among the options considered (i.e. a 25-year-old woman starts work and 10 years later she becomes pregnant). In this situation, the gap is in the most favourable scenario (i.e. "1") 22,802 . This amount is equivalent to approximately 30 monthly salaries.

For the management of household finances, it is not only the total loss resulting from motherhood that is important, but also how the reduced income deteriorates over time, as presented in Figure 3. This allows to observing the real decrease in the value of the mother's pay while on maternity and parental leave. In addition, it can be seen that the largest income gap is created within five years of becoming pregnant. During this time, the mother's wages are about $18 \%$ lower than a childless person if 
Table 1. Total amounts of net salaries (real values) in four variants of career development and differences between given variant and variant " 0 " in selected cases

\begin{tabular}{|c|c|c|c|c|c|c|c|c|}
\hline 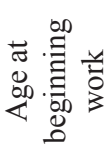 & 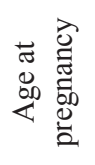 & $\begin{array}{l}\stackrel{\vec{\Xi}}{\vec{Z}} \\
\stackrel{\vec{J}}{J}\end{array}$ & $\underset{2}{\stackrel{*}{2}}$ & 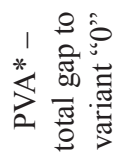 & 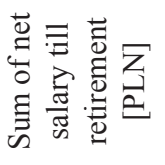 & 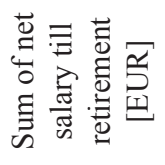 & 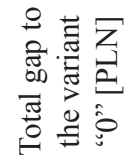 & 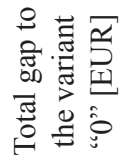 \\
\hline \multirow{12}{*}{20} & \multirow{4}{*}{21} & "0" & 766 & 0 & 2597862 & 604154 & 0 & 0 \\
\hline & & "1" & 720 & $-46,28$ & 2440983 & 567670 & -156879 & -36483 \\
\hline & & “2” & 699 & -67.71 & 2368319 & 550772 & -229543 & -53382 \\
\hline & & " $3 "$ & 711 & -55.75 & 2408878 & 560204 & -188984 & -43950 \\
\hline & \multirow{4}{*}{25} & “0” & 766 & 0 & 2597862 & 604154 & 0 & 0 \\
\hline & & "1" & 726 & -39.9 & 2462615 & 572701 & -135247 & -31453 \\
\hline & & “2” & 714 & -52.03 & 2421478 & 563134 & -176384 & -41020 \\
\hline & & “3” & 720 & -46.33 & 2440786 & 567625 & -157076 & -36529 \\
\hline & \multirow{4}{*}{30} & " $0 "$ & 766 & 0 & 2597862 & 604154 & 0 & 0 \\
\hline & & "1" & 733 & -33.11 & 2485631 & 578054 & -112231 & -26100 \\
\hline & & " $2 "$ & 727 & -38.86 & 2466124 & 573517 & -131738 & -30637 \\
\hline & & “3” & 730 & -36.5 & 2474134 & 575380 & -123728 & -28774 \\
\hline \multirow{12}{*}{25} & \multirow{4}{*}{26} & “0” & 680 & 0 & 2303510 & 535700 & 0 & 0 \\
\hline & & "1" & 637 & -42.09 & 2160815 & 502515 & -142695 & -33185 \\
\hline & & "2" & 619 & -60.68 & 2097807 & 487862 & -205703 & -47838 \\
\hline & & "3" & 629 & -50.4 & 2132649 & 495965 & -170861 & -39735 \\
\hline & \multirow{4}{*}{30} & “0” & 680 & 0 & 2303510 & 535700 & 0 & 0 \\
\hline & & "1" & 644 & -35.71 & 2182447 & 507546 & -121063 & -28154 \\
\hline & & "2" & 633 & -46.14 & 2147109 & 499328 & -156402 & -36372 \\
\hline & & "3" & 638 & -41.31 & 2163465 & 503132 & -140045 & -32569 \\
\hline & \multirow{4}{*}{35} & “ 0 ” & 680 & 0 & 2303510 & 535700 & 0 & 0 \\
\hline & & "1" & 651 & -28.92 & 2205463 & 512898 & -98048 & -22802 \\
\hline & & " $2 "$ & 646 & -33.8 & 2188938 & 509055 & -114572 & -26645 \\
\hline & & “3” & 648 & -31.81 & 2195664 & 510619 & -107847 & -25081 \\
\hline
\end{tabular}

*PVA - present value of annuity multiplier.

Source: own calculations.

the pregnancy occurs one year after starting work, and by $12 \%$ lower than a childless person if the pregnancy is in the 5th or 10th year of the professional career, while the average income of the mother is $7 \%$ lower than the income of a childless woman.

Moreover, for women who get pregnant five years after starting work (and are 20 or 25 years old at the beginning of work), the distance from a childless person lasts even longer than five years, because a significant reduction is observed for 

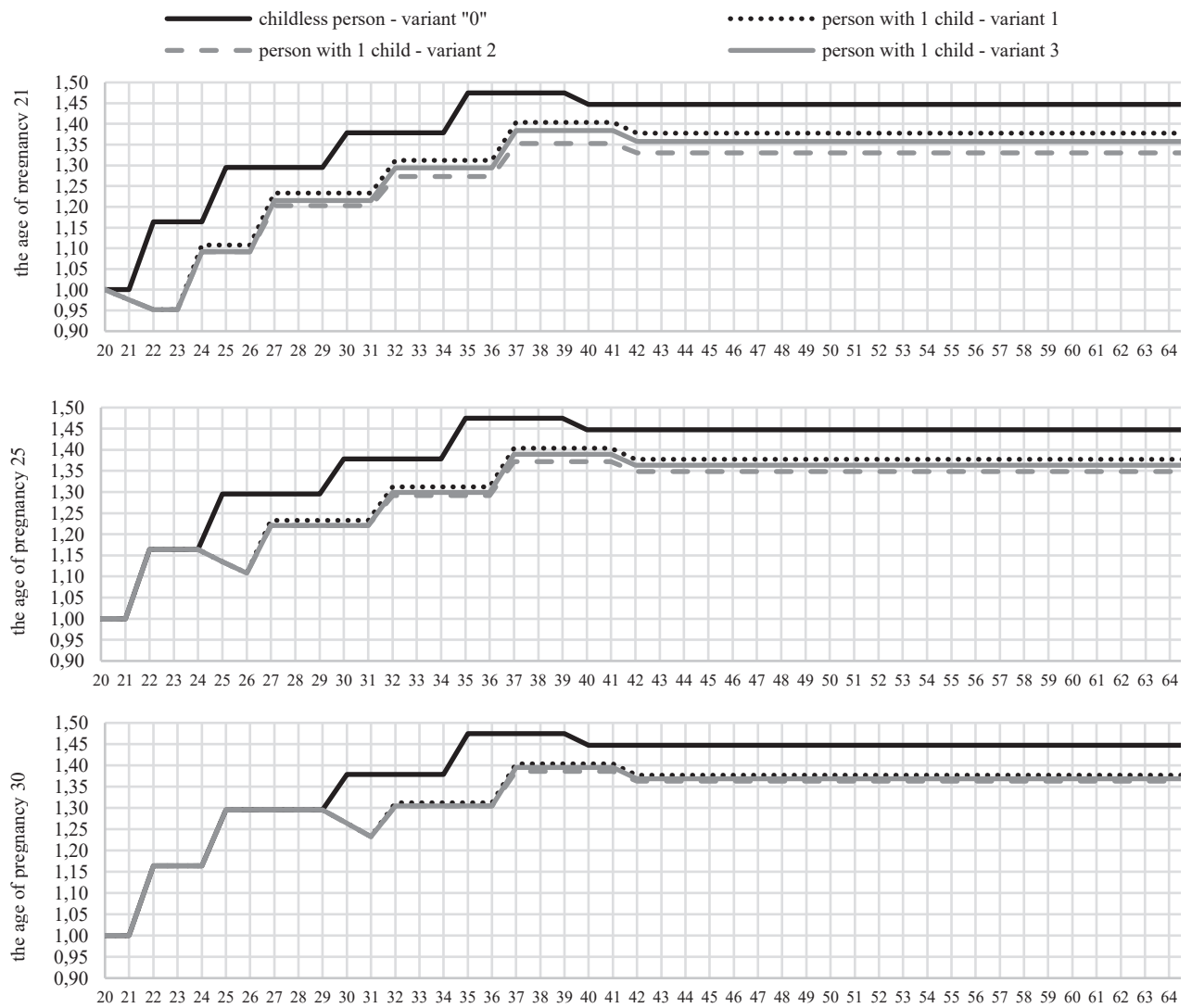

Fig. 3. Salary (real values) for a 20 -year-old woman

Source: own calculations.

up to 11 years. If this is related to households' financial purposes, spouses receive mortgage loans at the age of 30-40. Thus, having a child at this time has an impact on the mother's creditworthiness which may, therefore, postpone the completion of the purpose of buying a property.

\section{Conclusions}

The article aims to indicate the source of the income gap that affects the mother as a result of pregnancy and child-rearing. The presented model is universal, but it is shown using the example of Polish realities, e.g. the length of maternity leave, and the Polish economic parameters, but can easily be adapted to the reality of another market.

The described method of calculating the mother's remuneration gap includes many simplifications and assumptions. First of all, if the mother receives lower 
earnings, also her contributions to the pension fund are lower, and therefore she will receive a lower pension from the social system in the future. Secondly, the amount of remuneration in the article was based solely on seniority. Differences in the level of remuneration at the beginning of the job for a person without higher education and one with higher education (only at the moment of entering the labour market) was omitted. The differences in the rate of increase in wages depending on the profession and education were also not taken into account.

It would be also possible to introduce a different model to the calculations, e.g. an actuarial annuity, which also takes into account the probabilities of death for a mother. Finally, it would be useful to analyse the effect of giving birth to more than one child. The presented valuation model can be used to determine the amount of compensation for the indirectly affected person, in this case for the mother. In the compensation of personal damages, the loss for the victim's household is increasingly appreciated. This may be used in civil liability insurance (medical malpractice, MTPL). In addition, changes in the mother's career path can be the basis for determining the contribution of the spouse to the household. This contribution may be the basis for the division of property in divorce proceedings.

\section{References}

Becker, G. S. (1975). Human capital: A theoretical and empirical analysis, with special reference to education. New York: Columbia University Press for NBER.

Central Statistical Office. (2016). Structure of wages and salaries by occupation in October 2016.

Glass, J. (2004). Blessing or curse? Work-family policies and mother's wage growth over time. Work and Occupations, 31(3), 367-394.

Hofflander, A. (1966). The human life value: An historical perspective. The Journal of Risk and Insurance, 33(3), 381-391.

Jędrzychowska, A. (2015). Size of compensation for personal injuries offered by the current coverage plans in medical liability insurance. In V. Kajurová, and J. Krajicek (Eds.), European financial systems 2015 (Proceedings of the 12th International Scientific Conference, pp. 230-237). Masaryk University.

Jędrzychowska, A. (2017). Evaluation on the benefits costs to cover the needs arising from personal injury. Rozprawy Ubezpieczeniowe, 26(4), 79-93.

Jędrzychowska, A., and Kwiecień, I. (2015). Classification of work-related accidents as the basis of analysis of employer's liability risk and insurance decisions. In V. Kajurová, and J. Krajicek (Eds.), European financial systems 2015 (Proceedings of the 12th International Scientific Conference, pp. 238-245). Masaryk University.

Jędrzychowska, A., and Kwiecień, I. (2016). The issues concerning the valuation of claims annuities and compensations. In J. Monkiewicz, and M. Monkiewicz M. (Eds.), Current trends in bodily injury claims in MTPL insurance:2010-2015: Promotor 2016 report (pp. 34-38).

Jędrzychowska, A., and Kwiecień, I. (2019). Valuation of household losses in child's death cases for insurance purposes. In K. Jajuga, H. Locarek-Junge, L.T. Orłowski, and K. Staehr (Eds.), Contemporary trends and challenges in finance (Proceedings from the 4th Wroclaw International Conference in Finance, pp. 175-190). Springer. 
Jędrzychowska, A., and Poprawska, E. (2014). Personal injuries from motor third party liability insurance and the minimum guarantee fund (Systems thinking for a sustainable economy: Advancements in economic and managerial theory and practice: CD-ROM of proceedings. Refereed Proceedings of Business Systems Laboratory, Universitas, pp. 1-15).

Jędrzychowska, A., and Poprawska, E. (2016). Analysis of the problem of determining loss of income and sources for their financing. The case of personal injuries caused in traffic accidents, Transformations in Business \& Economics, 15(2A(38A)), 329-353.

Leimberg, S. R., Doyle, R. J., Jr., and Buck, K. A. (2nd edition). (1999). Tools and techniques of life insurance planning. Cincinnati, $\mathrm{OH}$ : The National Underwriter Company.

Letablier, M., Luci, A., Math, A., and Thévenon, O. (2009). The costs of raising children and the effectiveness of policies to support parenthood in European countries (Report for European Commission). European Communities.

Lips, H., and Lawson, K. (2009). Work values, gender, and expectations about work commitment and pay: Laying the groundwork for the "motherhood penalty"? Sex Roles, 61(9-10), 667-676.

Mielle, B., Misra, J., and Boeckmann, I. (2012). The motherhood penalty in cross-national perspective: The importance of work-family policies and cultural attitudes, Oxford Journal, 19(2), 163-193.

Murphy, R. P. (2006). The labor theory of value: A critique of Carson's studies in mutualist political economy. Journal of Libertarian Studies, 20(1), 17-33.

Ronka-Chmielowiec, W., Jędrzychowska, A., and Poprawska, E. (2015). The sufficiency of the minimum amounts in compulsory liability insurance to cover personal injury claims - based on motor third party liability insurance and medical liability insurance. Wiadomości Ubezpieczeniowe, (4), 79-102.

Schultz, T. W. (1961). Investment in human capital. American Economic Review, (51).

Staff, J., and Jaylen M. (2012). Explaining the motherhood penalty during the early occupational career. Demography, 49(1), 1-21.

Zelizer, V. (1994). Pricing the priceless child: The changing social value of children. Princeton, NJ: Princeton University Press. 